\title{
Differential processing of yolk proteins during oocyte hydration in marine fishes (Labridae) that spawn benthic and pelagic eggs
}

\author{
Roderick Nigel Finn ${ }^{1, *}$, Melissa Wamboldt ${ }^{2}$, Hans Jørgen Fyhn ${ }^{1}$ \\ ${ }^{1}$ Department of Zoology, University of Bergen, Allégaten 41, 5007 Bergen, Norway \\ ${ }^{2}$ Biology Department, Mt. St. Vincent University, Halifax, Nova Scotia B3M 2J6, Canada
}

\begin{abstract}
The yolk proteins and free amino acids (FAA) were investigated during oocyte maturation in 4 species of Labridae with either benthic or pelagic eggs. Benthic eggs and oocytes of both types had a small FAA pool dominated by taurine, while pelagic eggs had a large and characteristic FAA pool with about equal amounts of indispensable and dispensable amino acids. Electrophoresis (SDS-PAGE) of the yolk proteins revealed the presence of high molecular weight yolk proteins in the oocytes of all 4 species. In 2 species with benthic eggs (Labrus bergylta, L. mixtus), no buildup of an FAA pool occurred (nmol $\mu^{-1}$ dry mass) during final maturation, and the yolk protein profile remained essentially unchanged. In a third species (Crenilabrus melops) with benthic eggs, partial degradation of a $112 \mathrm{kDa}$ protein coincided with the buildup of a small FAA pool. In the species with pelagic eggs (Ctenolabrus rupestris), the buildup of a large FAA pool coincided with the disappearance of the $112 \mathrm{kDa}$ yolk protein. The calculated yield of FAA by hydrolysis of the disappearing fraction of the $112 \mathrm{kDa}$ yolk protein for both species matched well with the measured increase in the FAA pool. It is suggested that differential processing of the high molecular yolk proteins causes differences in teleost egg behaviour, benthic or pelagic.
\end{abstract}

KEY WORDS: Labridae $\cdot$ Wrasse $\cdot$ Oocyte hydration - Oocyte maturation · Proteolysis · Yolk proteins · Free amino acids

\section{INTRODUCTION}

It has recently been hypothesised that the success of the marine teleost group of fishes has a basis in biochemical changes occurring in the yolk compartment of the hydrating oocyte during maturation (Fyhn et al. 1999). It is argued that, due to the hyposmotic condition of the egg yolk of marine teleosts, there is an inescapable physiological demand for embryonic water to counteract the osmotic loss caused by the high salinity of the spawning environment. Thus, a reservoir of water must be transferred to the egg (i.e. the yolk) from the mother fish before spawning. The water

*E-mail: nigel.finn@zoo.uib.no problem is greatest during the early cellular phases of development, since marine teleost embryos apparently do not start drinking activity until shortly before or after hatching (Guggino 1980, Mangor-Jensen \& Adoff 1987, Riis-Vestergaard 1987, Tytler et al. 1993).

The great majority of marine teleosts, regardless of systematic affinities, are oviparous and spawn predominantly pelagic eggs (Kendall et al. 1984). Other marine teleosts spawn benthic eggs. These fishes are termed pelagophils and benthophils, respectively (LaFleur \& Thomas 1991, Finn et al. 2002). The Labridae are a family of exclusively marine teleosts that are highly diversified and include mostly tropical pelagophils but also some benthophils (Richards \& Leis 1984, Nelson 1994). Seven species of Labridae have been recorded in Norwegian waters (Quinard \& Pras 
1986, Pethon 1989, Sayer \& Treasurer 1996, Muus et al. 1999), and 4 are common in the coastal waters near Bergen. These are (taxonomy according to Wheeler 1992) the ballan wrasse Labrus bergylta, the cuckoo wrasse L. mixtus, the corkwing Crenilabrus melops and the goldsinny wrasse Ctenolabrus rupestris. The ballan and cuckoo wrasses are protogynous hermaphrodites and spawn benthic sticky eggs in maleguarded nests (Pethon 1989, Costello 1991). The corkwing also spawns benthic sticky eggs in male-guarded nests (Potts 1985, Skiftesvik et al. 1996, van der Meeren \& Lønøy 1998, Uglem \& Rosenquist 2001), but it is considered a polygynous, batch-spawning gonochore (Dipper \& Pullin 1979, Stone 1996, Uglem et al. 2000). In contrast to these benthophils, the batch-spawning females of goldsinny wrasse are enticed to release pelagic eggs in a male-guarded territory (Hilldén 1984, Quignard \& Pras 1986, Stone 1996). The goldsinny wrasse is also a polygynous gonochore (Hilldén 1984, Stone 1996). These 4 species were chosen as a related family group for the present study of the mechanism of oocyte hydration in marine teleosts.

Earlier studies of maturing oocytes of marine benthophils have shown a correlation between yolk proteolysis and hydration of the egg (Wallace \& Selman 1985, Greeley et al. 1986, 1991, McPherson et al. 1987, 1989). More recently, this has also been reported for marine pelagophils (Carnevali et al. 1992, 1993, Matsubara et al. 1995, 1999, Okumura et al. 1995, Matsubara \& Koya 1997, Finn et al. 2000, 2002, Reith et al. 2001). The hydration of the pelagic egg of marine teleosts has also been associated with the appearance of a large pool of free amino acids, FAA (Fyhn 1993, Matsubara \& Sawano 1995, Thorsen \& Fyhn 1996, Matsubara et al. 2000, Reith et al. 2001, Wright \& Fyhn 2001, Finn et al. 2002). The emerging FAA pool has a remarkably similar profile among the examined species (Thorsen \& Fyhn 1991, Thorsen et al. 1993, Rønnestad et al. 1996, Finn et al. 2002) and a phylogenetic implication has been suggested (Fyhn et al. 1999).

The present contribution expands on this topic by showing a differential processing of the yolk proteins correlated with differences in the emerging pool of free amino acids in benthic and pelagic eggs of closely related marine fishes.

\section{MATERIALS AND METHODS}

Sample collection. Three benthophil species of Labridae (the ballan wrasse Labrus bergylta, the cuckoo wrasse Labrus mixtus, the corkwing Crenilabrus melops) and 1 pelagophil species of Labridae (the goldsinny wrasse Ctenolabrus rupestris) were investigated.
Females were collected by trapping and gill-netting during their spring and summer spawning seasons in coastal waters near Bergen, Norway $\left(60^{\circ} \mathrm{N}, 5^{\circ} \mathrm{E}\right)$ and transported live to the Department of Zoology, University of Bergen, for dissection and analyses. Species were identified by colouring and meristic characters (Wheeler 1978, Quinard \& Pras 1986, Pethon 1989, Muus et al. 1999). Only females that had both prehydrated oocytes (PH ooc) and ovulated eggs (OV eggs) simultaneously present in their ovaries were used for the mechanistic studies. A total of 5 L. bergylta, 2 L. mixtus, 4 Crenilabrus melops, and 4 Ctenolabrus rupestris were investigated. The killed fishes (blow to the head) were immediately measured, weighed, and dissected in a cold room $\left(6^{\circ} \mathrm{C}\right)$. Standard lengths of the females were measured with a ruler, and their gonadosomatic index (GSI) was calculated according to Wootton (1990) following wet mass determination of the total ovaries and female bodies on a Sartorius (Type 1405 accuracy $\pm 0.1 \mathrm{mg}$ ) top balance. The GSIs of the studied females ranged from 7 to $11 \%$ except for $1 \mathrm{~L}$. bergylta with a GSI of $15 \%$.

Staging of the oocytes was established by size and degree of transparency, and they were classified as either $\mathrm{PH}$ ooc or OV eggs. Only the largest $\mathrm{PH}$ ooc were selected for dissection, and these were isolated and freed from adhering tissues with fine forceps. OV eggs were found free within the ovarian lumen, and were either rolled out or stripped from the excised ovaries. Individual PH ooc and OV eggs were freed of adhering fluid with lint-free filter paper (Kimwipes ${ }^{\circledR}$ ), pooled in sealed Eppendorf tubes ( $\mathrm{N}=10$ to $30 \mathrm{PH}$ оoс and 10 to $40 \mathrm{OV}$ eggs) for wet mass determination (Sartorius BP121S top balance, accuracy $\pm 0.1 \mathrm{mg}$ ). Samples were then immediately frozen at $-80^{\circ} \mathrm{C}$, and were stored at $-30^{\circ} \mathrm{C}$ until lyophilisation or extraction. Oocyte and egg dry masses were subsequently determined on a Cahn 25 Electrobalance (accuracy $\pm 1 \mu \mathrm{g}$ ) following $24 \mathrm{~h}$ of lyophilisation. Water contents (\% wet mass and $\mathrm{mg}$ ind.- ${ }^{-1}$ ) were calculated from the difference between wet and dry mass.

Oocyte and egg diameters were measured by placing separate sub-samples in FO medium (Wallace \& Selman 1978) in order to avoid gravitational flattening and desiccation. Diameters were determined for 20 to 30 individual oocytes or eggs from each female with a calibrated Wild binocular microscope at $50 \times$ magnification. No further analyses were performed on the sub-samples in FO media.

Analytical procedures. FAA analyses and quantitation and electrophoresis of proteins were carried out as follows:

Free amino acid analyses: Frozen samples were directly extracted $\left(24 \mathrm{~h}\right.$, rotated at $\left.4^{\circ} \mathrm{C}\right)$ in their original Eppendorf tubes with ice-cold 6\% trichloro-acetic acid 
(TCA). The extracts were then centrifuged $(14000 \times g$ for $10 \mathrm{~min}, 4^{\circ} \mathrm{C}$ ) and the supernatants were used for quantitation of FAA. FAA were determined by reversed-phase chromatography with a Gilson HPLC connected to an ASTED sample robot, fluorometric detection (OPA and FMOC reagents), Inertsil C3 column (thermostatted at $30^{\circ} \mathrm{C}$ ), and every tenth sample was compared to external standards (mixture of 24 amino acids). Appropriately diluted TCA was used as blanks. The amount of FAA is expressed per individual (nmol ind.$^{-1}$ ) and the terminology of indispensable and dispensable amino acids is used (Harper 1983).

Protein quantitation and electrophoresis: The TCA precipitates were washed once in $6 \%$ TCA, then solubilised in $1.0 \mathrm{M} \mathrm{NaOH}$ under rotation for 24 to $48 \mathrm{~h}$ at room temperature. Equal volumes of double-distilled water $\left(\mathrm{ddH}_{2} \mathrm{O}\right)$ were then added to give a final concentration of $0.5 \mathrm{M} \mathrm{NaOH}$, and a further $24 \mathrm{~h}$ of solubilisation was allowed prior to protein determination. Protein content was measured without the addition of surfactant using Bio-Rad's detergent compatible assay kit (Cat \# 500-0112), which is a micro-modification of the Lowry technique (Lowry et al. 1951). Assays were conducted in quadruplicate using bovine serum albumin (BSA) as standard, and read at $750 \mathrm{~nm}$ in an Anthos Labtec HTII microplate absorption photometer.

For electrophoresis of yolk proteins, lyophilised samples were homogenised in ice-cold buffer $(60 \mathrm{mM}$ HEPES, $150 \mathrm{mM} \mathrm{NaCl}, 50 \mu \mathrm{g} \mathrm{ml}^{-1}$ aprotinin, $\mathrm{pH}$ 7.5), and centrifuged at $10000 \times g, 5 \mathrm{~min}, 4^{\circ} \mathrm{C}$; the supernatants were aspirated to clean Eppendorf tubes. Soluble protein concentration was estimated using the BioRad detergent-compatible assay kit described above, and extracts were diluted to $0.8 \mu \mathrm{g} \mathrm{ul}^{-1}$ with reduced loading buffer $(2.5 \% \quad \beta$-mercapto-ethanol, $0.0625 \mathrm{M}$ Tris, $10 \%$ glycerol, $2 \%$ sodium dodecyl sulfate (SDS), $0.01 \%$ bromophenol blue, $\mathrm{pH}$ 6.8) and applied to duplicate $7.5 \% \mathrm{~T}, 3.3 \% \mathrm{C}$ homogeneous acrylamide/ bis-acrylamide gels $(0.75 \mathrm{~mm})$ using the buffer system of Schagger \& von Jagow (1987). The stacking gel consisted of $4 \% \mathrm{~T}, 3.3 \% \mathrm{C}$ acrylamide/bis-acrylamide. Samples were electrophoresed in a Bio-Rad Protean II cell at $95 \mathrm{~V}, 50 \mathrm{~mA}$ per gel for $80 \mathrm{~min}$, and the protein bands were visualised with Coomassie Brilliant Blue G-250. For estimation of the apparent molecular weight of the visualised protein bands, Bio-Rad precision prestained markers at 250, 150, 100, 75, 50, 37, 25 15, and $10 \mathrm{kDa}$ (Cat \# 161-0372) were applied to both sides of the gel. The gels were scanned with an Epson GT-9600 scanner using transmitted light, and the relative mobility $\left(R_{\mathrm{f}}\right)$ of the standards and yolk proteins was measured digitally at $160 \times$ magnification. Estimates of the apparent $M_{\mathrm{r}}$ of yolk proteins were calculated from fifth-order polynomials fitted to plots of $\log \left(M_{\mathrm{r}}\right)$ versus $R_{\mathrm{f}}\left(\mathrm{r}^{2}=0.9999\right)$. To improve the accuracy of the estimates of apparent $M_{\mathrm{r}}$ of the yolk proteins, the outermost lanes of the gel were excluded and the gels were run with excess anode buffer to reduce the smile effect. In addition, the $2 M_{\mathrm{r}}$ standards on either side of the gels were checked for precise post-scan alignment. The relative fraction of each band in the gels was established by densitometry of the scanned gels using the National Institutes of Health (NIH) Image 1.62 Analysis software.

Statistical differences at the 5\% level were determined via ANOVA according to the procedures of Sokal \& Rohlf (2000).

\section{RESULTS}

The $\mathrm{PH}$ ooc of the species that spawn benthic eggs, i.e. Labrus bergylta, L. mixtus and Crenilabrus melops, were similar in size $(620$ to $670 \mu \mathrm{m})$, while those of Ctenolabrus rupestris, which spawns pelagic eggs, were significantly $(\mathrm{p}<0.05)$ smaller $(463 \pm 38 \mu \mathrm{m}$ : Table 1). The relative water content of the $\mathrm{PH}$ ooc was 61 to $62 \%$ of wet mass in both benthophils and pelagophils, although the value for L. bergylta was higher. The most noteworthy change that occurred during oocyte maturation was the greater swelling of the pelagic OV eggs in C. rupestris, with wet mass increasing by a factor of 8.4, compared to a factor of 2 to 3 for the benthic eggs. This was due to a significantly ( $p<$ 0.05 ) greater hydration of the pelagic OV eggs, which reached a relative water content of $\sim 93 \%$ compared to 76 to $78 \%$ for the benthic OV eggs. The dry mass increased during oocyte maturation in all fishes, but much less than the concomitant increase in wet mass.

The protein content of the $\mathrm{PH}$ ooc of the 2 benthophils Labrus bergylta and L. mixtus increased significantly $(\mathrm{p}<0.05)$ during the hydration period, while that of the third benthophil, Crenilabrus melops, also increased, although not significantly. In contrast, the protein content of the $\mathrm{PH}$ ooc of the pelagophil Ctenolabrus rupestris significantly $(p<0.05)$ decreased in the OV eggs (Fig. 1). Although, due to their smaller size, the total protein content of the $\mathrm{PH}$ ooc of $C$. rupestris was lower than that of the benthophils', the mass-specific protein fraction was similar (68\% of dry mass compared to $56-70 \%$ of dry mass for the 3 benthophils. During the hydration period, the massspecific protein content did not change significantly ( $p>0.05)$ in the OV eggs of the 3 benthophils, but declined significantly $(\mathrm{p}<0.05)$ in the OV eggs of $C$. rupestris.

The FAA contents of both benthophil and pelagophil $\mathrm{PH}$ ooc were low and characterised by a dominance of the non-proteinic amino acid taurine, which made up 30 to $45 \%$ of the total FAA pool (Fig. 2). A small FAA 


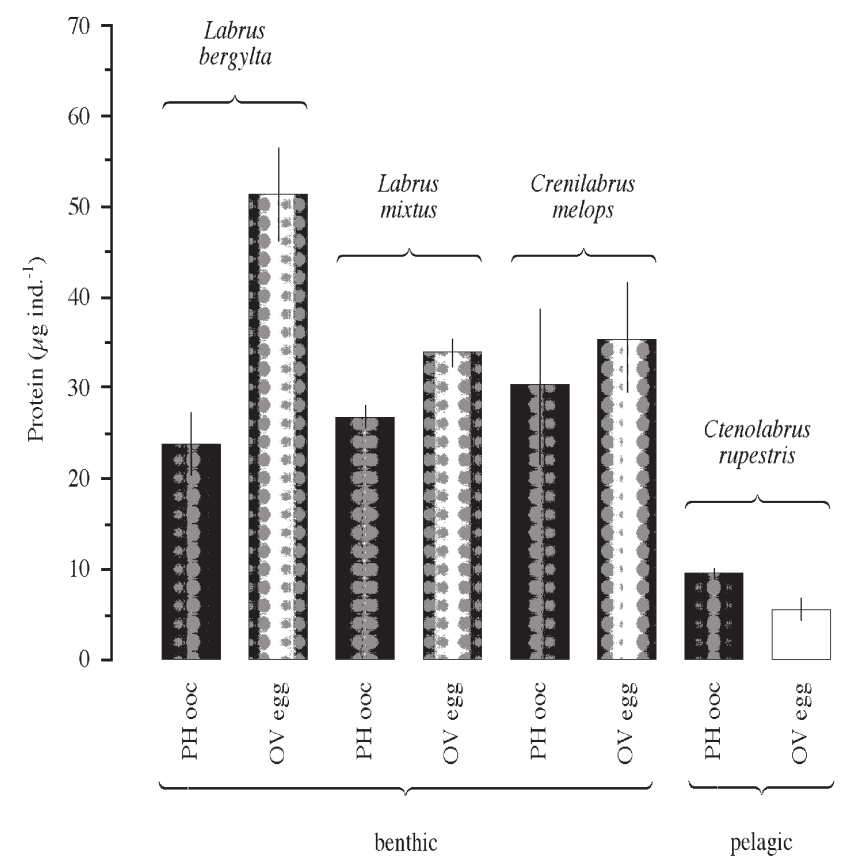

Fig. 1. Labridae. Protein content (mean $\pm \mathrm{SD}$ ) of pre-hydrating oocytes (PH ooc) and ovulated eggs (OV egg) of 4 species spawning benthic or pelagic eggs pool with taurine dominance was also found in the benthic OV eggs, although in the case of Crenilabrus melops the pool increased (Fig. 3). The most remarkable change, however, was in the pelagic OV eggs of Ctenolabrus rupestris, in which the FAA content increased strongly (factor of 8.6: Table 2) and thus also changed their profile compared to the $\mathrm{PH}$ ooc profile (Fig. 2). When normalised with respect to dry mass, the FAA content of $C$. rupestris increased significantly ( $\mathrm{p}<$ 0.05 ) from $\sim 4 \%$ of dry mass in the $\mathrm{PH}$ ooc to $19 \%$ in the OV eggs (Fig. 3). In comparison, no significant changes occurred in the FAA content of the 2 Labrus species during the hydration period, while in Crenilabrus melops it increased significantly $(\mathrm{p}<0.05)$ from 3 to $5 \%$ of the dry mass (Fig. 3). The appearance of the large FAA pool in the pelagic OV eggs of $C$. rupestris was due to increases in virtually all of the measured FAA, but particularly of the indispensable amino acids such that the contents of indispensable and dispensable amino acids became almost equal (Fig. 2, Table 2). In comparison, the distribution between indispensable and dispensable amino acids for the benthophils remained highly skewed, with a dominance of dispensable amino acids due to the high levels of taurine.

Table 1. Labridae. Biometric and gravimetric changes during oocyte hydration of 4 species. PH ooc: pre-hydration oocyte; OV egg: ovulated egg. N: number of replicate measurements of pooled samples; numbers in parentheses: total number of dissected oocytes or eggs in the pooled samples; SL: standard length. Swell factors calculated by dividing the measured wet mass of the ovulated eggs by that of the pre-hydrated oocytes

\begin{tabular}{|c|c|c|c|c|c|}
\hline \multirow[t]{2}{*}{ Variable } & \multicolumn{2}{|c|}{ PH ooc } & \multicolumn{2}{|c|}{ OV egg } & \multirow[t]{2}{*}{ Swell factor } \\
\hline & $\mathrm{N}$ & Mean $\pm \mathrm{SD}$ & $\mathrm{N}$ & Mean $\pm \mathrm{SD}$ & \\
\hline \multicolumn{6}{|c|}{ Labrus bergylta (benthic) } \\
\hline \multicolumn{6}{|c|}{2 females, SL: $25+29 \mathrm{~cm}$} \\
\hline Diameter $(\mu \mathrm{m})$ & 60 & $670 \pm 50$ & 60 & $880 \pm 20$ & \multirow{4}{*}{2.7} \\
\hline Wet mass $\left(\mu \mathrm{g}\right.$ ind.$\left.^{-1}\right)$ & $16(200)$ & $139 \pm 25$ & $16(225)$ & $379 \pm 26$ & \\
\hline Dry mass ( $\mu \mathrm{g}$ ind.$\left.^{-1}\right)$ & $8(99)$ & $41 \pm 6$ & $8(109)$ & $92 \pm 3$ & \\
\hline $\mathrm{H}_{2} \mathrm{O}(\%)$ & & $70.5 \pm 2.4$ & & $75.7 \pm 1.6$ & \\
\hline \multicolumn{6}{|c|}{ Labrus mixtus (benthic) } \\
\hline 1 female, SL: $16 \mathrm{~cm}$ & & & & & \multirow{5}{*}{2.0} \\
\hline Diameter $(\mu \mathrm{m})$ & 30 & $620 \pm 30$ & 30 & $770 \pm 20$ & \\
\hline Wet mass $\left(\mu \mathrm{g}\right.$ ind..$\left.^{-1}\right)$ & $8(144)$ & $114 \pm 7$ & $8(153)$ & $230 \pm 6$ & \\
\hline Dry mass ( $\mu \mathrm{g}$ ind.$\left.^{-1}\right)$ & $4(63)$ & $44 \pm 3$ & $4(91)$ & $54 \pm 0.4$ & \\
\hline $\mathrm{H}_{2} \mathrm{O}(\%)$ & & $61.4 \pm 1.6$ & & $76.5 \pm 0.3$ & \\
\hline \multicolumn{6}{|c|}{ Crenilabrus melops (benthic) } \\
\hline \multicolumn{6}{|c|}{2 females, SL: $17+18 \mathrm{~cm}$} \\
\hline Diameter $(\mu \mathrm{m})$ & 46 & $630 \pm 60$ & 32 & $814 \pm 66$ & \multirow{4}{*}{2.4} \\
\hline Wet mass ( $\mu$ g ind..$\left.^{-1}\right)$ & $16(286)$ & $110 \pm 26$ & $16(162)$ & $260 \pm 18$ & \\
\hline Dry mass $\left(\mu g\right.$ ind $\left.^{-1}\right)$ & $7(146)$ & $43 \pm 18$ & $7(83)$ & $56 \pm 5$ & \\
\hline $\mathrm{H}_{2} \mathrm{O}(\%)$ & & $61.0 \pm 5.8$ & & $78.0 \pm 4.8$ & \\
\hline \multirow{2}{*}{\multicolumn{6}{|c|}{$\begin{array}{l}\text { Ctenolabrus rupestris (pelagic) } \\
2 \text { females, SL: } 8.1+10.5 \mathrm{~cm}\end{array}$}} \\
\hline & & & & & \multirow{5}{*}{8.4} \\
\hline Diameter $(\mu \mathrm{m})$ & 60 & $463 \pm 38$ & 60 & $863 \pm 27$ & \\
\hline Wet mass $\left(\mu \mathrm{g}\right.$ ind..$\left.^{-1}\right)$ & $16(274)$ & $37 \pm 9$ & $16(189)$ & $311 \pm 31$ & \\
\hline Dry mass $\left(\mu g\right.$ ind $\left.^{-1}\right)$ & $6(106)$ & $14 \pm 2$ & $8(101)$ & $23 \pm 1$ & \\
\hline $\mathrm{H}_{2} \mathrm{O}(\%)$ & & $62.2 \pm 4.3$ & & $92.6 \pm 0.7$ & \\
\hline
\end{tabular}




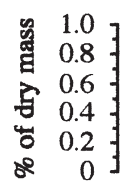

Mean for all benthic spawners

$\left.\begin{array}{r}0.8 \\ 0.6 \\ 0.4 \\ 0.2 \\ 0\end{array}\right]$

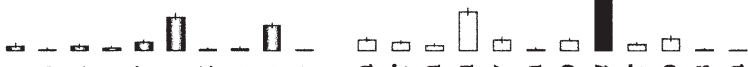

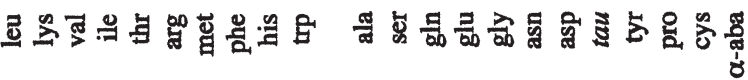

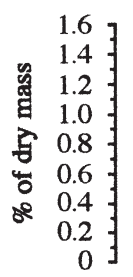

Ctenolabrus rupestris

nillonoll $\|_{\text {mati. }}$

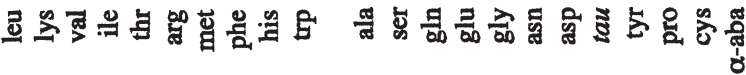

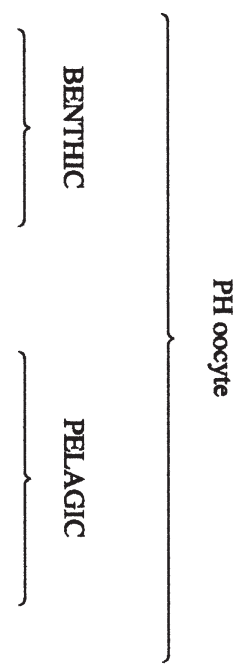

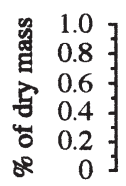

Labrus bergylta

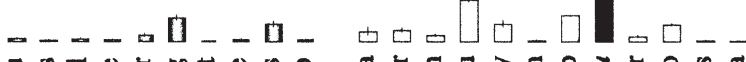

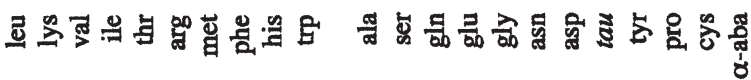

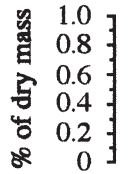

Labrus mixtus

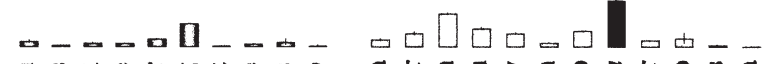

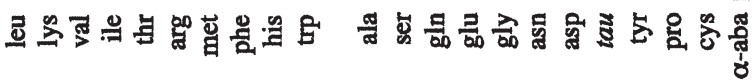

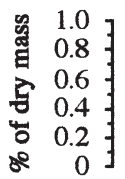

Crenilabrus melops

1000巾0七00.
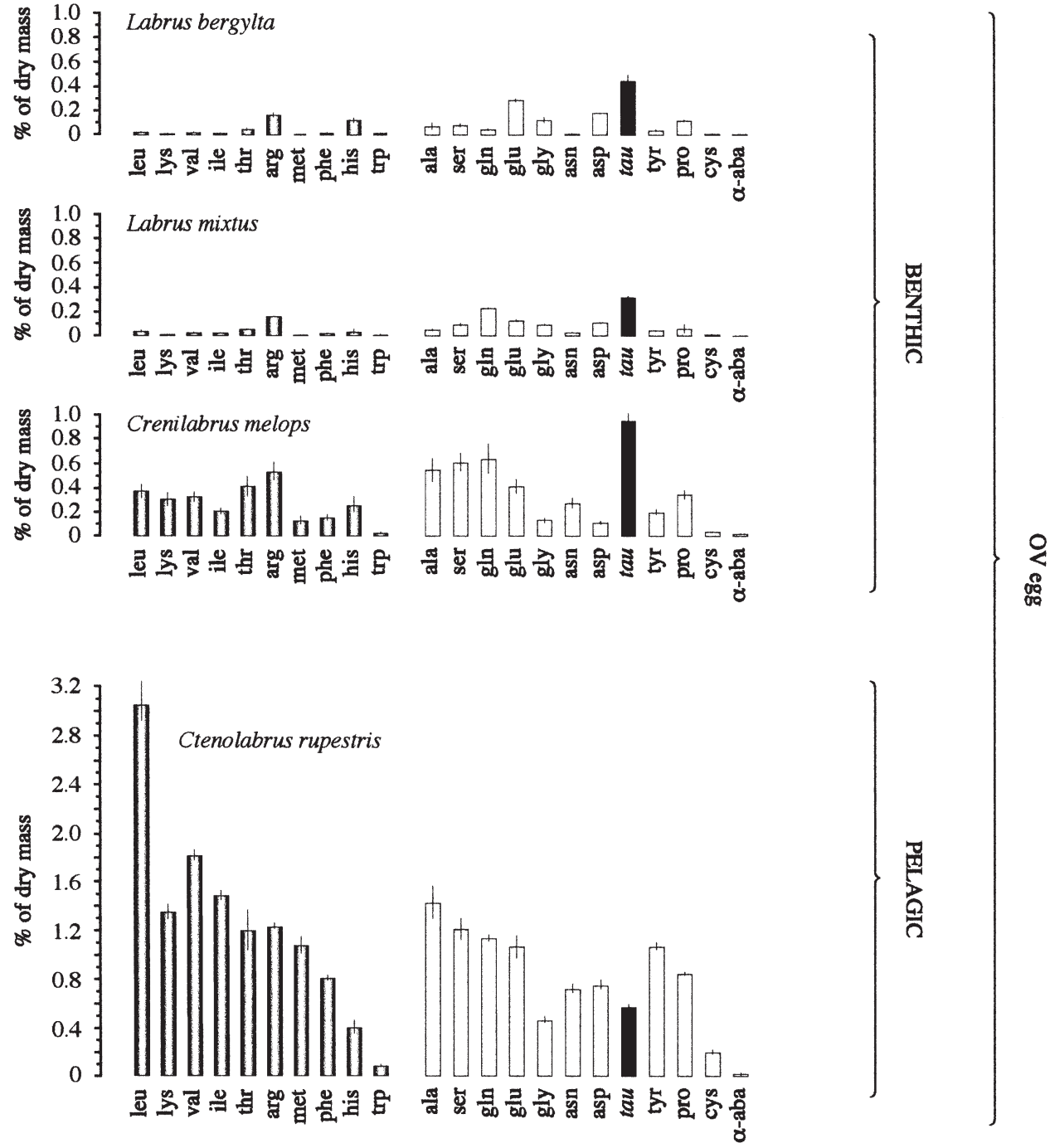

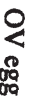

indispensable

dispensable

Fig. 2. Labridae. Content (means $\pm \mathrm{SD}$ ) of free amino acids in pre-hydrating oocytes (PH ooc) and ovulated eggs (OV egg) of 4 species spawning benthic or pelagic eggs. Values have been normalised for size differences by multiplying the molar values of each amino acid with its molecular mass and expressing as a weight percent of the total oocyte or egg dry mass 
Table 2. Labridae. Total contents (mean $\pm \mathrm{SD}$ ) of free amino acids ( $\sum$ FAA, nmol ind. ${ }^{-1}$ ) and the percent distribution (in parentheses) of the indispensable and dispensable (\% of total) amino acids in pre-hydration ( $\mathrm{PH}$ ooc) and ovulated eggs (OV eggs) of 4 species

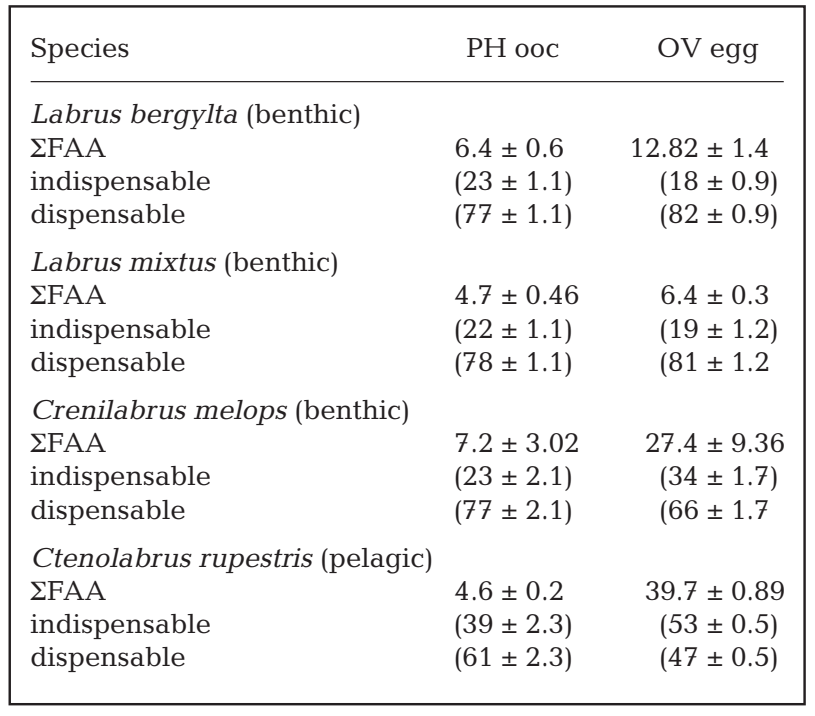

Electrophoresis of the yolk proteins revealed a coincidence between a band shift and the appearance of the FAA pool during oocyte hydration. For Labrus bergylta, which maintained constant mass-specific amounts of FAA (Fig. 3), the major protein bands at 107,100 , and $73 \mathrm{kDa}$, and a minor band at $34 \mathrm{kDa}$ in

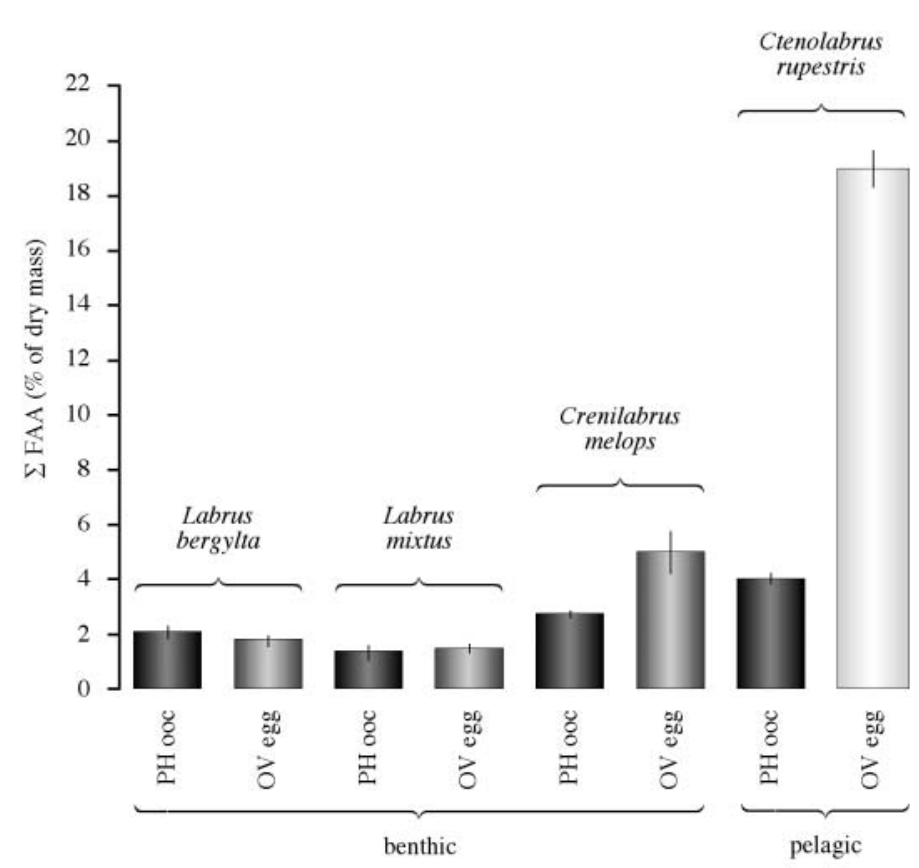

Fig. 3. Labridae. Total content (means \pm SD) of free amino acids ( $\Sigma \mathrm{FAA}$ ) in pre-hydrating oocytes (PH ooc) and ovulated eggs (OV egg) of 4 species spawning benthic or pelagic eggs the PH ooc were also present in the OV eggs (Fig. 4). Similarly, for L. mixtus, which also showed no change in the mass-specific FAA content, the major bands at $112,91,71 \mathrm{kDa}$ and minor bands at 22 and $20 \mathrm{kDa}$ were also found in the OV eggs, although the $112 \mathrm{kDa}$ protein may have decreased in quantity. In contrast, significant changes occurred in the protein profiles of Crenilabrus melops, in which in particular a major band at $112 \mathrm{kDa}(41 \%$ of the proteins are localised at this band, as determined by densitometry) disappeared, while bands at 72 and $22 \mathrm{kDa}$ appeared.

The most notable changes in the electrophoretic yolk protein profile occurred in the pelagic eggs of Ctenolabrus rupestris concurrent with the large increase in the FAA pool. The major band at $112 \mathrm{kDa}(43 \%$ of the proteins are localised at this band, as determined by densitometry) and the less dominant bands at 97,65, and $57 \mathrm{kDa}$, as well as the minor bands at 77,22 , and $20 \mathrm{kDa}$ in the $\mathrm{PH}$ ooc, all disappeared during the hydration period. In contrast, new bands (in particular a major band at $21 \mathrm{kDa}$ but also minor bands at 92 and $75 \mathrm{kDa}$ ) were found in the OV eggs.

\section{DISCUSSION}

Group-synchronous ovaries and batch-spawning are typical for oviparous marine pelagophils, i.e. the majority of marine teleosts (Kendall et al. 1984), but batch-spawning also occurs in freshwater benthophils such as the crucian carp Carassius carassius (Aho \& Holopainen 2000) or the freshwater goby Micropercops swinhonis (Iwata et al. 2001). In batch-spawning, several 'batches' of the oocytes are induced to undergo final maturation at different times, with the result that several egg batches are released within a reproductive season. The simultaneous presence of both OV eggs and $\mathrm{PH}$ ooc (the latter being in the majority) in each of the 4 species of Labridae studied reveals that these fishes have group-synchronous ovaries. Both the benthophil Crenilabrus melops and the pelagophil Ctenolabrus rupestris are recognised batch-spawners (Dipper \& Pullin 1979, Dipper 1984, Stone 1996, Uglem et al. 2000), but to our knowledge little information exists on the spawning habits or mating system of the 2 benthophils Labrus bergylta and L. mixtus, although their group-synchronous ovaries suggest that they have batch-spawning potential. Further studies will clarify their spawning habits and mating system.

The physiological data show that the studied species of Labridae utilise different mechanisms for hydrating their oocytes, depending on 
whether benthic or pelagic eggs will be produced. In the 2 benthophil Labrus species, virtually no change occurred in the electrophoretic protein profiles or in the FAA pool during oocyte maturation. Rather, these fishes (L. bergylta and L. mixtus) continued sequestering yolk proteins during final maturation, and the concomitant hydration was relatively small. Although we cannot preclude that the $\mathrm{PH}$ ooc of $L$. bergylta were in a mid-vitellogenic phase, a continued protein sequestration is known to occur during the early phases of oocyte maturation (germinal vesicle migration) in other benthophils (Wallace \& Selman 1985, Thorsen et al. 1993, Tyler \& Sumpter 1996), and the degree of hydration is similar to earlier reports on marine benthophils (Craik \& Harvey 1986, Greeley et al. 1986). Furthermore, the early phases of oocyte maturation in some teleosts may last several weeks (Mylonas et al. 1997). The increased protein content and lack of change in either the protein or FAA profiles suggest that oocyte hydration in the studied species of Labridae is mainly driven by transport of inorganic ions, as shown for the benthophil Fundulus heteroclitus (Greeley et al. 1986, 1991, Thorsen \& Fyhn 1991, Wallace et al. 1992).

Intriguingly, Crenilabrus melops, which also spawns benthic eggs, showed an altered yolk protein profile and some increase in the FAA pool during oocyte hydration. This indicates participation of another hydration mechanism. The increase in the FAA pool coincided with the disappearance of the $112 \mathrm{kDa}$ protein band in the $\mathrm{PH}$ ooc and the appearance of a band at $72 \mathrm{kDa}$ and another band at $22 \mathrm{kDa}$ in the OV eggs. Recently, Matsubara et al. (1999), studying the pelagophil Verasper moseri, demonstrated that 2 high molecular weight yolk proteins (107 and $94 \mathrm{kDa}$, respectively) are the heavy chains of lipovitellins derived from 2 forms of vitellogenin. Similar studies for the pelagophil Melanogrammus aeglefinus argued that the observed high molecular weight yolk proteins were also derived from 2 forms of vitellogenin (Reith et al. 2001). In both these species (Matsubara et al. 1999, Reith et al. 2001) only one of the high molecular weight proteins was hydrolysed, while the other yolk protein was nicked. Based on the present methodology, we cannot determine whether the observed yolk proteins of $C$. melops are homologous to those of $V$. moseri or $M$. aeglefinus, although the change in the electrophoretic profile with the concurrent rise in FAA during oocyte maturation of $C$. melops suggests a similar mechanism in the species. This notion is strengthened by the experiments of Thorsen \& Fyhn (1996), who demonstrated with oocyte cultures of the plaice Pleuronectes platessa, a teleost with pelagic eggs, that the increase in egg FAA pool was not caused by transport from an extracellular source. Furthermore, since densitometry of C. melops $\mathrm{PH}$ ooc proteins revealed that

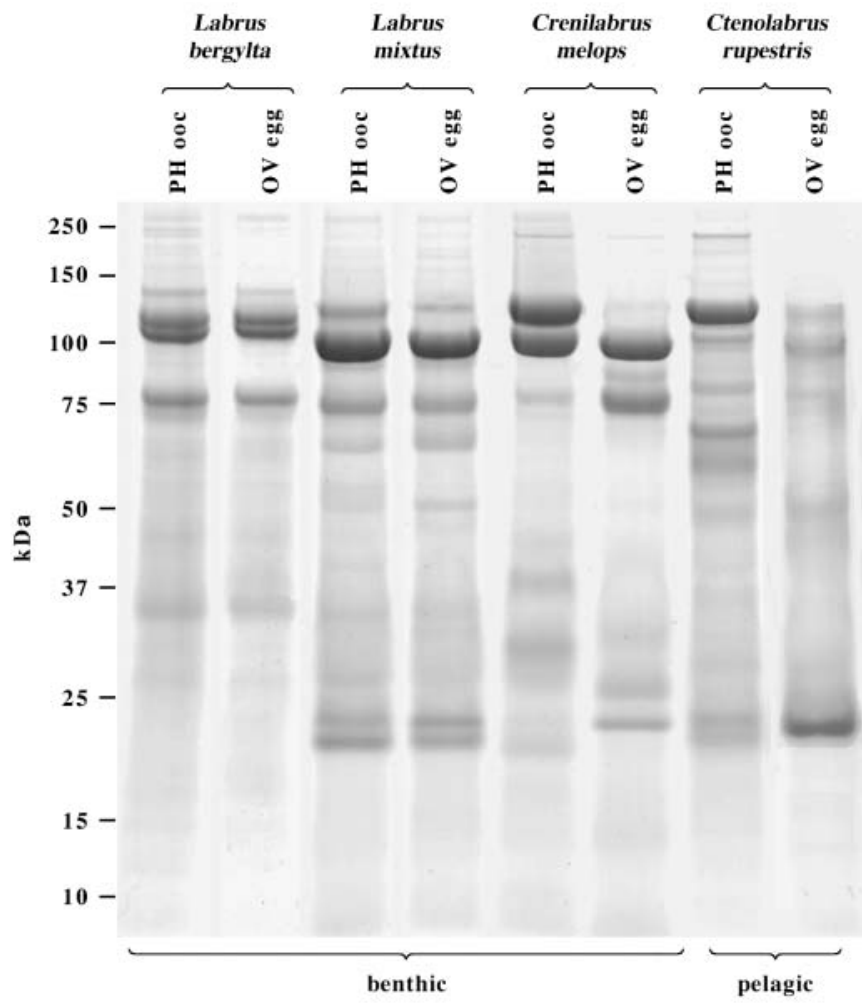

Fig. 4. Labridae. Coomassie Brilliant Blue G-250 stained 7.5\% homogeneous SDS-PAGE gels of yolk proteins in pre-hydrating oocytes (PH ooc) and ovulated eggs (OV egg) of 4 species spawning benthic or pelagic eggs. Molecular weight standards are shown on left

the $112 \mathrm{kDa}$ band that disappeared during oocyte hydration accounted for $41 \%$ of the $30.4 \mu \mathrm{g}$ ind.$^{-1}$ yolk protein, hydrolysis of an $18 \mathrm{kDa}$ fragment would be necessary to generate an $18 \mathrm{nmol}$ FAA ind. ${ }^{-1}$ increase in the OV eggs, whereas actually an increase of 20 nmol FAA ind. ${ }^{-1}$ was found during this period (Table 2). This calculation is based on an average polymerised amino acid molecular weight of $110 \mathrm{~g} \mathrm{~mol}^{-1}$ for the amino acid pool in question, and taurine is excluded. The loss of such an $18 \mathrm{kDa}$ from the original $112 \mathrm{kDa}$ protein could explain the novel OV egg proteins of 72 and $22 \mathrm{kDa}$ (Fig. 4). Further molecular characterisation is necessary to verify this possibility.

For the pelagophil Ctenolabrus rupestris, in which a larger increase in the FAA pool occurred, there seems to be a greater contribution of the $112 \mathrm{kDa}$ yolk protein. A major portion of this protein $(43 \%$ of the $9.5 \mu \mathrm{g}$ oocyte proteins) seems to be split or fully hydrolysed, since mainly a protein band of $\sim 21 \mathrm{kDa}$ exists in the $\mathrm{OV}$ eggs. Using the same calculation procedure as for Crenilabrus melops, the hydrolysis of the disappearing $91 \mathrm{kDa}$ fragment should generate $30 \mathrm{nmol}$ FAA ind. ${ }^{-1}$, whereas actually $35 \mathrm{nmol}$ ind. $^{-1}$ was measured (Table 2). The fact that there is a substantial 
increase in the indispensable amino acids in the egg FAA pool supports the inference of yolk protein hydrolysis. At present, however, we are unable to account for the disappearance of the 64 and $57 \mathrm{kDa}$ bands during the hydration phase. Furthermore, the calculations do not take into account sequence-specific binding of Coomassie Brilliant Blue G-250, or of the presence of highly anionic proteins such as the phosvitins which may be present in teleost yolk (Wallace \& Bergovac 1985, Murakami et al. 1991, Losso et al. 1993, Goulas et al. 1996, Matsubara et al. 1999, 2000, Wang et al. 2000).

It has been well documented that vitellogenin is the major source of yolk proteins in osteichthyan fishes (Ng \& Idler 1983, Mommsen \& Walsh 1988, Specker \& Sullivan 1994, Johanning \& Specker 1995, Tyler \& Sumpter 1996), but only recently have multiple forms of vitellogenin been reported in teleosts. Multiple forms of vitellogenin, have been found in freshwater benthophils (Kishida \& Specker 1993, Lee et al. 1994, Trichet et al. 2000, Wang et al. 2000), in marine benthophils (LaFleur et al. 1995), as well as in marine pelagophils (Matsubara et al. 1999, Reith et al. 2001). These latter studies have further mapped some of the oocyte proteins to the different vitellogenin cDNAs and argued that their hydrolysis was part of the mechanism that generates the FAA pool in pelagic fish eggs. It seems probable, based on the findings in the present study, that the Labridae also possess at least 2 forms of vitellogenin giving rise to the 2 high molecular weight proteins (107 to $112 \mathrm{kDa}$ and 90 to $96 \mathrm{kDa}$ bands) found in the $\mathrm{PH}$ ooc of all 4 species.

Since the Labridae species are found exclusively in marine habitats, with the majority spawning pelagic eggs in tropical environments (Richards \& Leis 1984), the 3 benthophil species in the present study are apparently among the minority in this family of fishes. Demersal eggs of marine fishes have been associated with cooler coastal environments, but are also phylogenetically an old character associated with ancient groups such as osmerids and clupeoids (Hempel 1984). As members of the order Perciformes, the Labridae are of recent evolutionary origin (Long 1995, Helfman et al. 1999), and thus comply with the suggestion that demersal spawning has developed independently in several groups (Hempel 1984). The differential processing of the yolk proteins concurrent with the appearance of a variable FAA pool, as observed in the present study, may have intriguing implications for the evolution of the benthic or pelagic character of teleost eggs.

Acknowledgements. We wish to thank Maria Sula Evjen for analytical assistance. Financial support for this study was provided by the Reseach Council of Norway (project no. 121695/122). This is contribution no. 113 of the research locus Early Life History of Marine Fish at the University of Bergen.

\section{LITERATURE CITED}

Aho J, Holopainen IJ (2000) Batch spawning of crucian carp (Carassius carassius [L.]) in mono- and multispecies communities. Ann Zool Fenn 37:101-111

Carnevali O, Mosconi G, Roncarati A, Belvedere P, Romano M, Limatola E (1992) Changes in the electrophoretic pattern of the yolk proteins during vitellogenesis in gilthead seabream Sparus aurata L. Comp Biochem Physiol B 103: 955-962

Carnevali O, Mosconi G, Roncarati A, Belvedere P, Limatola E, Polzonetti-Magni AM (1993) Yolk protein changes during oocyte growth in European seabass Dicentrarchus labrax L. J Appl Ichthyol 9:175-184

Costello MJ (1991) A review of the biology of wrasse (Labridae) in northern Europe. Prog Underw Sci 16:29-51

Craik JCA, Harvey SM (1986) Phosphorus metabolism and water uptake during final maturation of ovaries of teleosts with pelagic and demersal eggs. Mar Biol 90:285-289

Dipper FA (1984) The strange sex lives of British wrasse. New Sci 14(May):444-445

Dipper FA, Pullin RSV (1979) Gonochorism and sex-inversion in British Labridae (Pisces). J Zool 187:97-112

Finn RN, Fyhn HJ, Norberg B, Munholland J, Reith M (2000) Oocyte hydration as a key feature in the adaptive evolution of teleost fishes to seawater. In: Norberg B, Kjesbu OS, Taranger GL, Anderson E, Stefansson SO (eds) Proc Sixth Int Symp Reproductive Physiology of Fish. Institute of Marine Research, Bergen, p 289-291

Finn RN, Østby G, Norberg B, Fyhn HJ (2002) In vivo oocyte hydration in Atlantic halibut (Hippoglossus hippoglossus). Proteolytic liberation of free amino acids, and ion transport are driving forces for osmotic water influx. J Exp Biol 205:211-224

Fyhn HJ (1993) Multiple functions of free amino acids during embryogenesis in marine fishes. In: Walther BT, Fyhn HJ (eds) Physiological and biochemical aspects of fish development. University of Bergen, Bergen, p 299-308

Fyhn HJ, Finn RN, Reith M, Norberg B (1999) Yolk protein hydrolysis and oocyte free amino acids as key features in the adaptive evolution of teleost fishes to seawater. Sarsia 84:451-456

Goulas A, Triplett EL, Taborsky G (1996) Isolation and characterization of a vitellogenin cDNA from rainbow trout (Oncorhynchus mykiss) and the complete sequence of a phosvitin coding segment. DNA Cell Biol 15:605-616

Greeley MS Jr, Calder DR, Wallace RA (1986) Change in teleost yolk proteins during oocyte maturation: correlation of yolk proteolysis with oocyte hydration. Comp Biochem Physiol B 84:1-9

Greeley MS Jr, Hols H, Wallace RA (1991) Changes in size, hydration, and low molecular weight osmotic effectors during meiotic maturation of Fundulus oocytes in vivo. Comp Biochem Physiol A 100:639-647

Guggino WB (1980) Water balance in embryos of Fundulus heteroclitus and F. bermudae in seawater. Am J Physiol 238:36-41

Harper AE (1983) Dispensable and indispensable amino acid interrelationships. In: Blackburn GL, Grant JP, Young VR (eds) Amino acids: metabolism and medical applications. John Wright, PSG, Boston, p 105-121

Helfman GS, Collette BB, Facey DE (1999) The diversity of fishes. Blackwell Science, Oxford

Hempel G (1984) Early life history of marine fish: the egg stage. A Washington Sea Grant Publication, Division of Marine Resources, University of Washington

Hilldén NO (1984) Behavioural ecology of the labrid fishes 
(Teleostei: Labridae) at Tjärnö on the Swedish west coast. PhD thesis, Department of Zoology, Stockholm University Iwata A, Sakai H, Shibukawa K, Jeon SR (2001) Developmental characteristics of a freshwater goby, Micropercops swinhonis, from Korea. Zool Sci (Tokyo) 18:91-97

Johanning KM, Specker JL (1995) Characterization of yolk proteins during oocyte development of tilapia, Oreochromis mossambicus. Comp Biochem Physiol B 112:177-189

Kendall AW, Ahlstrom EH, Moser HG (1984) Early life history stages of fishes and their characters. Spec Publ Am Soc Ichthyol Herpetol 1:11-22

Kishida M, Specker JL (1993) Vitellogenin in tilapia (Oreochromis mossambicus): induction of two forms by estradiol, quantification in plasma and characterization in oocyte extract. Fish Physiol Biochem 12:171-182

LaFleur GJ Jr, Thomas P (1991) Evidence for a role of $\mathrm{Na}^{+}{ }^{+} \mathrm{K}^{+}-$ ATPase in the hydration of Atlantic croaker and spotted seatrout oocytes during final maturation. J Exp Zool 258: $126-136$

LaFleur GJ Jr, Byrne BM, Haux C, Greenberg RM, Wallace RA (1995) Liver-derived cDNAs: vitellogenin and vitelline envelope protein precursors (choriogenins). In: Goetz FW, Thomas P (eds) Proc Fifth Int Symp Reproductive Physiology of Fish. University of Texas, Austin, p 336-338

Lee BH, Lim EH, Lam TJ, Ding JL (1994) Two major groups of vitellogenin cDNA clones from Oreochromis aureus (Steindachner). Biochem Mol Biol Int 34:75-83

Long JA (1995) The rise of fishes. 500 million years of evolution. Johns Hopkins University Press, Baltimore

Losso JN, Bogumil R, Nakai S (1993) Comparative-studies of phosvitin from chicken and salmon egg-yolk. Comp Biochem Physiol B 106:919-923

Lowry OH, Rosebrough NJ, Farr AL, Randall RJ (1951) Protein measurement with the folin phenol reagent. J Biol Chem 193:265-275

Mangor-Jensen A, Adoff GR (1987) Drinking activity of the newly hatched larvae of cod Gadus morhua L. Fish Physiol Biochem 3:99-103

Matsubara T, Koya Y (1997) Course of proteolytic cleavage in three classes of yolk proteins during oocyte maturation in barfin flounder Verasper moseri, a marine teleost spawning pelagic eggs. J Exp Zool 278:189-200

Matsubara T, Sawano K (1995) Proteolytic cleavage of vitellogenin and yolk proteins during vitellogenin uptake and oocyte maturation in barfin flounder (Verasper moseri). J Exp Zool 272:34-45

Matsubara T, Adachi S, Ijiri S, Yamauchi K (1995) Change of lipovitellin during in vitro oocyte maturation in Japanese flounder Paralichthys olivaceus. Fish Sci 61:478-481

Matsubara T, Ohkubo N, Andoh T, Sullivan CV, Hara A (1999) Two forms of vitellogenin, yielding two distinct lipovitellins, play different roles during oocyte maturation and early development of barfin flounder, Verasper moseri, a marine teleost that spawns pelagic eggs. Dev Biol 213:18-32

Matsubara T, Ohkubo N, Andoh T, Sullivan CV, Hara A (2000) Involvement of dual-vitellogenin system in the control mechanism of egg buoyancy in barfin flounder and walleye pollock. In: Norberg B, Kjesbu OS, Taranger GL, Anderson E, Stefansson SO (eds) Proc Sixth Int Symp Reproductive Physiology of Fish. Institute of Marine Research, Bergen, p 305

McPherson R, Greeley MS, Wallace RA (1987) The role of yolk proteolysis in the hydration of Fundulus heteroclitus oocytes during meiotic maturation. Am Zool 27:A91

McPherson R, Greeley MS, Wallace RA (1989) The influence of yolk protein proteolysis on hydration in the oocytes of Fundulus heteroclitus. Dev Growth Differ 31:475-483
Mommsen TP, Walsh PJ (1988) Vitellogenesis and oocyte assembley. In: Hoar WS, Randall DJ (eds) Fish physiology. XIA. Academic Press, New York, p 347-406

Murakami M, Iuchi I, Yamagami K (1991) Partial characterisation and subunit analysis of major phosphoproteins of egg-yolk in the fish, Oryzias latipes. Comp Biochem Physiol B 100:587-593

Muus BJ, Nielsen JG, Dahlstrøm P, Nyström BO (1999) Sea fish. Scandinavian Fishing Year Book, Hedehusene

Mylonas CC, Woods LC, Zohar Y (1997) Cyto-histological examination of post-vitellogenesis and final oocyte maturation in captive-reared striped bass. J Fish Biol 50:34-49

Nelson JS (1994) Fishes of the world. John Wiley \& Sons, New York

Ng TB, Idler DR (1983) Yolk formation and differentiation in teleost fishes. In: Hoar WS, Randall DJ (eds) Fish physiology. IX. Academic Press, New York, p 373-404

Okumura H, Kayaba T, Kazeto Y, Hara A, Adachi S, Yamauchi K (1995) Changes in the electrophoretic patterns of lipovitellin during oocyte development in the Japanese eel Anguilla japonica. Fish Sci 61:529-530

Pethon P (1989) Aschehougs store fiskebok: alle norske fisker i farger. H Aschehoug, Stockholm (in Norwegian)

Potts GW (1985) The nest structure of the corkwing wrasse, Crenilabrus melops (Labridae: Teleostei). J Mar Biol Assoc UK 65:531-546

Quignard JP, Pras A (1986) Labridae. In: Whitehead PJP, Bauchot ML, Hureau JC, Nielsen J, Tortonese E (eds) Fishes of the North-eastern Atlantic and the Mediterranean. UNESCO, Richard Clay, Bungay, p 919-942

Reith M, Munholland J, Kelly J, Finn RN, Fyhn HJ (2001) Lipovitellins derived from two forms of vitellogenin are differentially processed during oocyte maturation in haddock (Melanogrammus aeglefinus). J Exp Zool Mol Dev Evol 291:58-67

Richards WJ, Leis JM (1984) Labroidei: development and relationships. Special Publ Am Soc Ichthyol Herpetol 1: 542-547

Riis-Vestergaard J (1987) Physiology of teleost embryos related to environmental challenges. Sarsia 72:351-358

Rønnestad I, Robertson R, Fyhn HJ (1996) Free amino acids and protein content in pelagic and demersal eggs of tropical marine fishes. In: MacKinlay DD, Eldridge M (eds) The fish egg. American Fisheries Society, Bethesda, MD, p 81-84

Sayer MDJ, Treasurer JW (1996) North European wrasse: identification, distribution and habitat. In: Sayer MDJ, Treasurer JW, Costello MJ (eds) Wrasse: biology and use in aquaculture. Fishing News Books, Oxford, p 3-12

Schagger H, von Jagow G (1987) Tricine-sodium dodecyl sulfate-polyacrylamide gel electrophoresis for the separation of proteins in the range from 1 to $100 \mathrm{kDa}$. Anal Biochem 166:368-379

Skiftesvik AB, Boxaspen K, Parsons A (1996) Preliminary breeding trials of wrasse in an intensive system. In: Sayer MDJ, Treasurer JW, Costello MJ (eds) Wrasse: biology and use in aquaculture. Fishing News Books, Oxford, p 136-141

Sokal RR, Rohlf FJ (2000) Biometry: the principles and practice of statistics in biological research, 4 th edn. WH Freeman, New York

Specker JL, Sullivan CV (1994) Vitellogenesis in fishes: status and perspectives. In: Davey KG, Peter RG, Tobe SS (eds) Perspectives in comparative endocrinology. National Research Council Canada, Ottawa, p 304-315

Stone J (1996) Preliminary trials on the culture of goldsinny and corkwing wrasse. In: Sayer MDJ, Treasurer JW, 
Costello MJ (eds) Wrasse: biology and use in aquaculture. Fishing News Books, Oxford, p 142-167

Thorsen A, Fyhn HJ (1991) Osmotic effectors during preovulatory swelling of marine fish eggs. In: Scott AP, Sumpter JP, Kime DE, Rolfe MS (eds) Proc Fourth Int Symp Reproduction of Fish University of East Anglia, Norwich, p 312-314

Thorsen A, Fyhn HJ (1996) Final oocyte maturation in vivo and in vitro in marine fishes with pelagic eggs; yolk protein hydrolysis and free amino acid content. J Fish Biol 48: 1195-1209

Thorsen A, Fyhn HJ, Wallace RA (1993) Free amino acids as osmotic effectors for oocyte hydration in marine fishes. In: Walther BT, Fyhn HJ (eds) Physiological and biochemical aspects of fish development. University of Bergen, Norway, p 94-98

Trichet V, Buisine N, Mouchel N, Moran P, Pendas AM, Le Pennec JP, Wolff J (2000) Genomic analysis of the vitellogenin locus in rainbow trout (Oncorynchus mykiss) reveals a complex history of gene amplification and retroposon activity. Mol Gen Genet 263:828-837

Tyler C, Sumpter JP (1996) Oocyte growth and development in teleosts. Rev Fish Biol Fish 6:287-318

Tytler P, Bell MV, Robinson J (1993) The ontogeny of osmoregulation in marine fish: effects of changes in salinity and temperature. In: Walther BT, Fyhn HJ (eds) Physiological and biochemical aspects of fish development. University of Bergen, Norway, p 249-258

Uglem I, Rosenqvist G (2001) Nest building and mating in relation to male size in corkwing wrasse Symphodus melops L. Environ Biol Fish 63:17-25

Uglem I, Rosenqvist G, Wasslavik HS (2000) Phenotypic variation between dimorphic males in corkwing wrasse. J Fish Biol 57:1-14

Editorial responsibility: Howard Browman (Contributing Editor), Storebø, Norway van der Meeren T, Lønøy T (1998) Use of mesocosms in larval rearing of saithe [Pollachius virens (L.)], goldsinny [Ctenolabrus rupestris (L.)], and corkwing [Crenilabrus melops (L.)]. Aquacult Eng 17:253-260

Wallace RA, Bergovac PC (1985) Phosvitins in Fundulus oocytes and eggs. Preliminary chromatographic and electrophoretic analysis together with biological considerations. J Biol Chem 260:11268-11274

Wallace RA, Selman K (1978) Oogenesis in Fundulus heteroclitus. I. Preliminary observations on oocyte maturation in vivo and in vitro. Dev Biol 62:354-369

Wallace RA, Selman K (1985) Major protein changes during vitellogenesis and maturation of Fundulus oocytes. Dev Biol 110:492-498

Wallace RA, Greeley MS Jr, McPherson R (1992) Analytical and experimental studies on the relationship between $\mathrm{Na}^{+}, \mathrm{K}^{+}$, and water-uptake during volume increases associated with Fundulus oocyte maturation in vitro. J Comp Physiol Biochem B 162:241-248

Wang H, Yan T, Tan JTT, Gong Z (2000) A zebrafish vitellogenin gene $(v g 3)$ encodes a novel vitellogenin without a phosvitin domain and may represent a primitive vertebrate vitellogenin gene. Gene 256:303-310

Wheeler A (1978) Key to the fishes of northern Europe. Willian Clowes \& Sons, London

Wheeler A (1992) A list of the common and scientific names of the fishes of the British Isles. J Fish Biol 41(Suppl B): $1-37$

Wootton RJ (1990) Ecology of teleost fishes. Chapman \& Hall, London

Wright P, Fyhn HJ (2001) Ontogeny of nitrogen metabolism and excretion. In: Anderson PM, Wright PA (eds) Fish physiology, Vol 20. Nitrogen excretion. Academic Press, London, p 145-201

Submitted: April 4, 2001; Accepted: December 17, 2001 Proofs received from author(s): June 24, 2002 